\title{
CHEMICAL AND MICROBIOLOGICAL EVALUATION OF THE INTERNAL SURFACES OF ALUMINUM TUBES BOTH UNLINED AND LINED WITH EPOXI RESIN BY MEANS OF THE STEREOSCOPE AND SCANNING ELECTRON MICROSCOPE
}

\author{
Elisabeth Loshchagin Pizzolitto $^{1 *}$; Antonio Carlos Pizzolitto ${ }^{1}$ Gilberto Luiz Pozetti $^{2}$ \\ ${ }^{1}$ Faculdade de Ciências Farmacêuticas. ${ }^{2}$ Instituto de Química, Universidade Estadual Paulista, Araraquara, SP, Brasil
}

Submitted: May 15, 2001; Returned to authors for corrections: August 03, 2001; Approved: December 14, 2001

\begin{abstract}
The internal surfaces of aluminum tubes, both unlined and lined with epoxy resin, which are used for packaged medicines such as creams, ointments, gels, etc., were evaluated chemically, and microbiologically with regard to microorganism adherence. Proof of porosity of the unlined aluminum surface and lined with epoxy resin, and the resistance to removal of the resin were observed using a scanning electron microscope and a stereoscope, with a digitalized image system. To evaluate the microorganisms adherence to the aluminum surface, unlined and lined with epoxy resin, sterilized disks (10 $\mathrm{mm}$ in diameter) were immersed in Mueller Hinton Broth and placed in tubes of polypropylene with screw caps. The liquid culture medium was then inoculated with suspensions $\left(10^{9} \mathrm{CFU} / \mathrm{ml}\right)$ of the following microorganisms: Streptococcus agalactiae, Staphylococcus aureus, Acinetobacter lwoffii and Candida albicans and incubated at $37^{\circ} \mathrm{C}$ under constant agitation (100rpm) for 12 days. The culture broth was changed every 3 days, after which the disks were removed, and observed under the scanning electron microscope. Microscopic observations revealed adherence of the microorganisms and biofilm on the aluminum surfaces both unlined and lined with epoxy resin.
\end{abstract}

Key words: Microbial adherence, biofilm, biofouling, aluminum packaging.

\section{INTRODUCTION}

The benefical or non-benefical effects of the microorganisms on surfaces have been known for centuries. Guy de Chaulic first noted the effects of foreign bodies on the subsequent healing of wounds in the $14^{\text {th }}$ century A. D.. The first detailed description of microbial adherence on surfaces was made by Zobell (19) and in 1970 the word biofilm was introduced into the scientific literature (9). Biofilms are defined as an accumulation of cells immobilized on a substratum in a matrix of extracellular polysaccharides of microbial origin (5).

The effects of microorganisms on surfaces is now almost universally accepted. There are many different types of surfaces preferred by microbes (9). The presence of biofilm on a surface can have many different types of effects, i.e. in the field of health where the quality of water is extremely important in industrial processing (9).

One of the detrimental effects of biofilms is that they can cause tooth decay, biocorrosion on metallic surfaces, and contamination of industrialized food and pharmaceutical products (3).

Walker et al. (18) concluded that no surface could be considered microbiologically clean. Microorganisms are present in water even in low numbers and can use a solid interface as a substratum for colonization. Lucas et al. (12) warned against the use of aluminum tubes as containers for medicines because of possible alterations, and Martindale (13) observed that on the aluminum lid used in containers for liquid medicines with sugar, a black polysaccharide formed. In 1988 Pozetti (16) observed that medicines in the form of gel could suffer alterations when packaged in aluminum tubes lined with epoxy resin.

\footnotetext{
* Corresponding author. Mailing address: Rua Expedicionários do Brasil, 1916. 14801-360, Araraquara, SP, Brasil. Fax: (+5516) 232-0880. E-mail: pizzolel@fcfar.unesp.br
} 
According to the National Agency of Sanitary Vigilance (1) in RDC n ${ }^{\circ} 33 / 2000$, under the item "Labelling and Packaging", recipients for hand made medicines should guaranty physical and chemical properties, and microbiological stability. Tubes used in pharmaceutical packaging are usually made of $99.5 \%$ commercialy pure aluminum plus secondary substances such as ferric oxide, silicium, and titanium (16). The aluminum forms a passive layer of oxide on the surface, and as a consequence improves resistance to corrosion (7).

The aluminum used to produce tubes for pharmaceutical packaging have a smooth surface resulting from cold process lamination varying in thickness from 0.00635 to $0.200 \mathrm{~mm}$ and possessing special characteristics resistant to destruction of the lining, toxicity, and porosity (2).

The objective of the present study was to evaluate, using chemical and microbiological methods, the behavior of commercially pure aluminum surfaces, both unlined and lined with epoxy resin to be used in the manufacture of tubes for the packaging of medicines for external use in alopathic, homeopathic or phitotherapic medicine.

\section{MATERIALS AND METHODS}

\section{Commercially pure aluminum unlined}

To evaluate the porosity of the unlined aluminum surface, rectangular pieces of different sizes, were cut from unlined aluminum tubes before being filled with medicines, and then submitted to the action of a 5\% (p/v) solution of mercury chloride for 5 minutes, according to CBE-Bandeirante de Embalagens Ltda (4).

\section{Commercially pure aluminum lined with epoxy resin}

To test the porosity of the epoxy resin lining the aluminum surface and the resistance to removal of the lining, rectangles of different sizes were cut from aluminum tubes lined with epoxy resin ready to receive the medicines. The samples were submitted to the action of a solution of $20 \%(\mathrm{v} / \mathrm{v})$ ammonium hydroxide for 3 hours, followed by friction with cotton swabs for lining removal, according to instructions of CBE-Bandeirante de Embalagens Ltda (4).

\section{Microbiological Evaluation}

For microbiological evalutions of the unlined and lined aluminum surface with epoxy resin, disks of $10 \mathrm{~mm}$ in diameter, were cut from the same tubes above mentioned.

The microorganisms Streptococcus agalactiae, Staphylococcus aureus and Acinetobacter lwoffii were cultivated in Blood Agar and Candida albicans were cultivated in Sabouraud Dextrose Agar, all mediums used were from Difco (10). These microorganisms were chosen because they are isolated with facility from biological and industrial environments. Suspensions were made in a Brain Heart Infusion and incubated at $37^{\circ} \mathrm{C}$ until an optical density of $1.0(540 \mathrm{~nm})$ was reached; $200 \mu \mathrm{l}$ of each cellular suspension $\left(10^{9} \mathrm{UFC} / \mathrm{ml}\right)$ was used to inoculate $15 \mathrm{ml}$ of Mueller Hinton Broth. The metallic samples were autoclaved at $121^{\circ} \mathrm{C}$ for $15 \mathrm{~min}$. and placed in $50 \mathrm{ml}$ polypropylene tubes [Corning] (8), containing $15 \mathrm{ml}$ of inoculated Mueller Hinton Broth, and incubated at $37^{\circ} \mathrm{C}$ under constant agitation of 100 revolutions per minute. The culture medium was changed every 3 days at 12 day intervals. After which the samples were removed from the liquid culture medium, prepared and examined using the scanning electron microscope (15).

\section{Electron Microscope Procedures}

The samples were immersed in $2.5 \%$ glutaraldehyde in $0.1 \mathrm{M}$ phosphate buffer ( $\mathrm{pH} 7.1)$ to fix the microorganisms, dehydrated in aqueous solutions of ethanol $(15,30,50,70,95$ and $100 \%)$ for $15 \mathrm{~min}$. each one, and dried in a centrifuge under vacuum, then coated with gold and examined under the scanning electron microscope JEOL-JSM [T330A] (15).

\section{RESULTS AND DISCUSSION}

Samples of aluminum unlined and lined with epoxy resin, obtained from tubes used for packaging medicines, were submitted to chemical evaluation with regard to the porosity. The surface observed macroscopically showed the formation of an amalgam of aluminum on the epoxy resin lined surface, after treatment with $5 \% \mathrm{HgCl}_{2}$. A chemical reaction was observed because the surface lined with epoxy resin was shown to be porous. The mercury chloride had reacted with the aluminum producing an alloy of mercury and aluminum easily observed. As a control aluminum samples without lining were used. According to the literature, porosity can be an undesirable factor, as the pores lead to stress and diminish mechanical resistence (14).

Regarding the proof of resistance to removal of the lining, a parcial removal of the resin was observed after an aluminum surface treatment with $20 \%$ ammonium hydroxide and friction with cotton swabs. This proof is used in order to verify the resin adherence on the aluminum surface.

In the present study, the physical surface of aluminum lined with epoxy resin was observed using the Leica (MZ12) stereoscope microscope showing an invasion of the external lining as well as flaws in the internal lining. Sharp points of aluminum and flaws in application of the resin were also noted, according to Pozetti (17).

The tubes of aluminum used in pharmaceutical packaging can at times show defects such as: internal or external dirt, foreign bodies, or deformed tubes, extremities of tubes either deformed or torn; breaks in the body of the tube when pressed, and other defects in production. On the internal lining following alterations can occur: high porosity, low adherence or elasticity of the resin, high solubility in acetone; low resistance to ammonia and acetic 
acid; the resin can also be rough, and non uniform. The interior resin could be contaminated by the exterior coating, and thus transfer particles of grease or oil into the product, according to CBE- Bandeirante de Embalagens Ltda. (4).

Bacterial adherence and biofilm formation on a commercially pure aluminum surface, lined with epoxy resin, was observed after samples incubation in Mueller Hinton Broth inoculated with Streptococcus agalactiae (Fig. 1), Candida albicans (Fig. 2), Staphylococcus aureus (Fig. 3), and on an unlined surface, Acinetobacter lwoffii (Fig.4), Staphylococcus aureus (Fig. 5) and Candida albicans (Fig. 6).

The microbiological evaluations observed using scanning electron microscope showed that the surface lined with epoxy resin, attracted a microbial colonization (Figs 1-3) and also, according to Montanaro, Arciola (14), and Pizzolitto et al. (15), the microorganisms seemed to have a preference for irregular or porous surfaces. These types of surfaces furnish niches in which the microorganisms can attract, stick to, and grow in microcolonies forming biofilms. It was also observed there was a microbial adherence on unlined aluminum surfaces (Figs. 4-6). Our results coincide with those of other researcher (12) who disapprove the use of aluminum tubes even those which are lined, due the fact that the contents prepared using plants such as hamamelis, aromatic chamomile, eucalyptus, etc., are incompatible with metallic salts, including those of aluminum. Aluminum can also form inumerous complexes of all the groups, both soluble and insoluble. Aluminum can precipitate $\mathrm{Ag}, \mathrm{Cu}$, $\mathrm{Hg}, \mathrm{Sn}, \mathrm{Sb}, \mathrm{Cd}$, etc., by reduction (6). According to Lucas (12) aluminum is incompatible with mercury salts, and in general

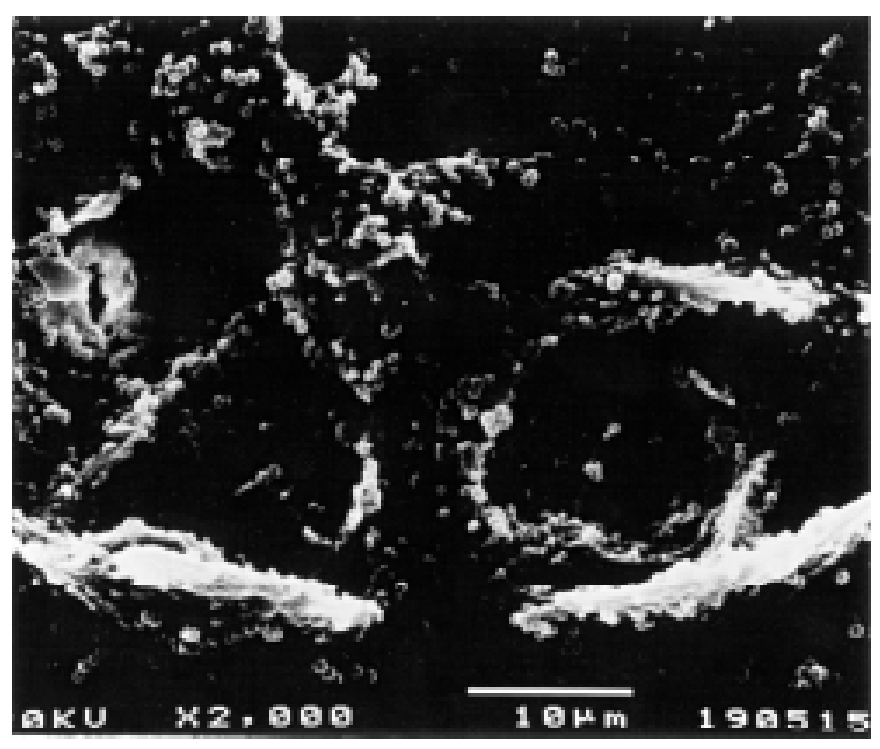

Figure 1. Scanning electron micrograph of slime enclosed communities of Streptococcus agalactiae on aluminum lined with epoxy resin (x2.000) JEOL-JSM T330A.

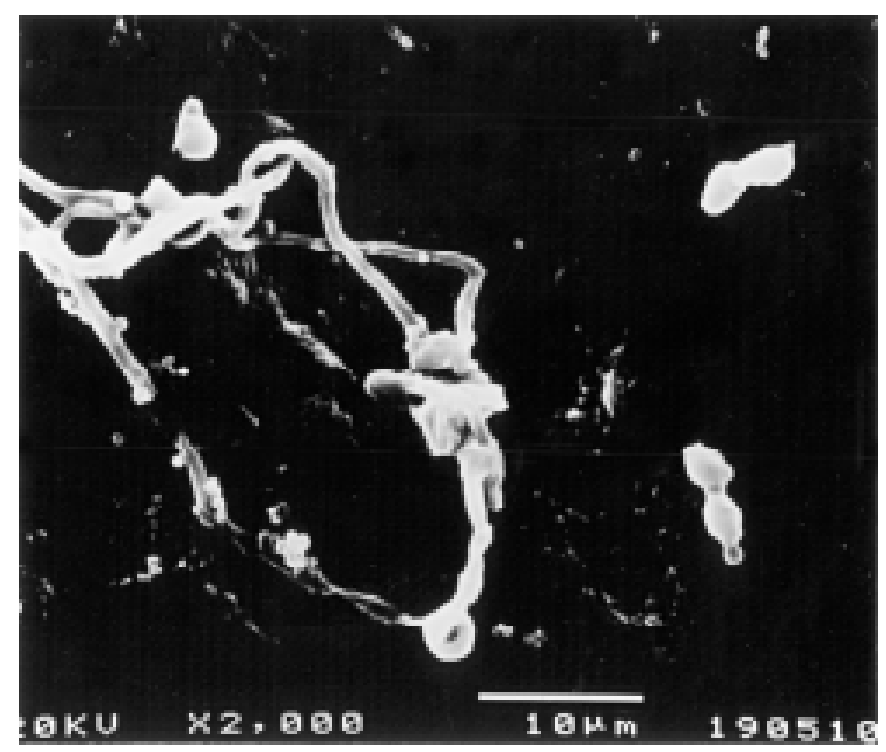

Figure 2. Scanning electron micrograph of Candida albicans hiphae on aluminum lined with epoxy resin (x2.000) JEOL-JSM T330A.

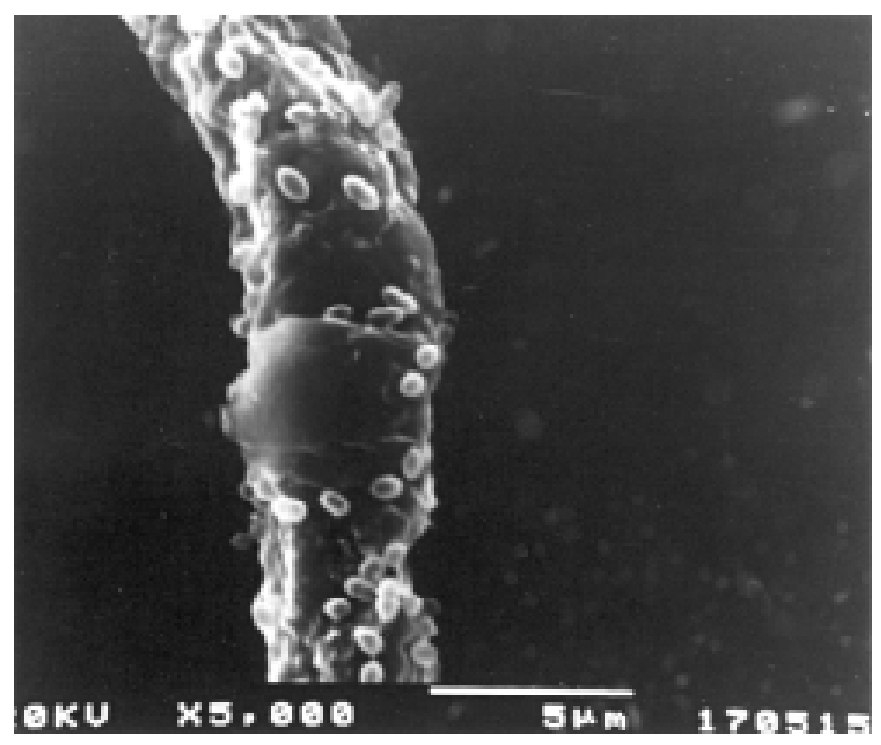

Figure 3. Scanning electron micrograph of Staphylococcus aureus adhesion on a sharp point as flaws of an aluminum lined with epoxy resin (x5.000) JEOL-JSM T330A.

with alkalis, alkaline carbonates, acid and acids salts in general. In reference to tubes manufactured using aluminum lined with epoxy resin Clark et al. (7) observed that this resin is incompatible with vegetable oils, gums, resins, and cellulosic polymer. Pozetti (17) recommended that the metallic tubes should not be used as recipients for products used in oral hygiene, homeopathic, 


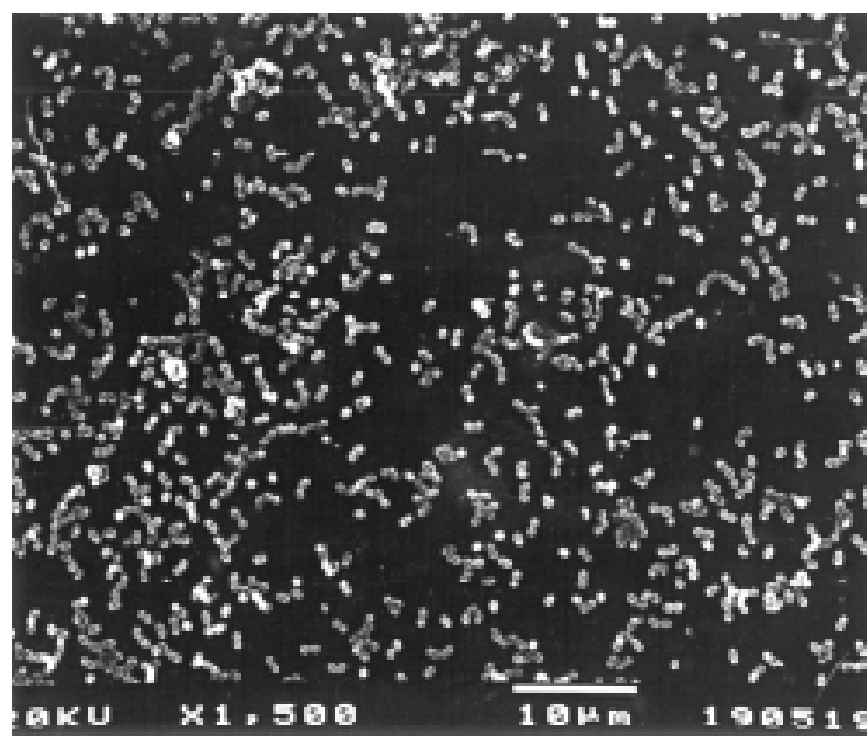

Figure 4. Scanning electron micrograph of Acinetobacter lwofii biofilm observed on aluminum unlined surface (x1.500) JEOLJSM T330A.

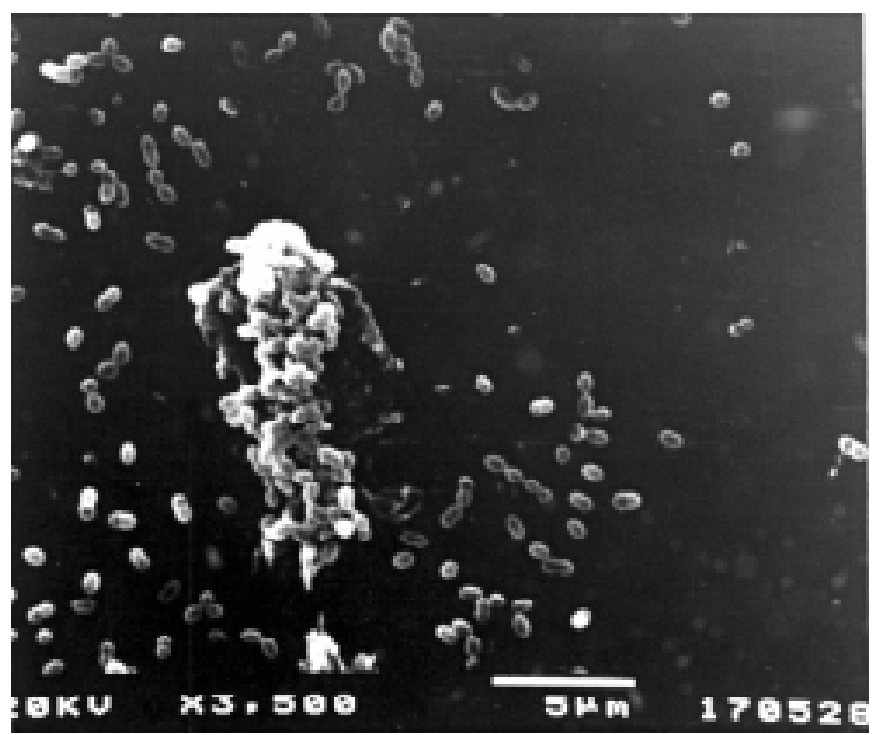

Figure 5. Scanning electron micrograph of slime enclosed communities of Staphylococcus aureus observed on aluminum unlined surface (x3.500) JEOL-JSM T330A.

alopathic and phitotherapic medicines. According to Ferreira (11) pharmaceutical packaging should be clean, and non interact physically or chemically with the contents. The quality and purity of the preparation, must be preserved and should be paint resistant, protecting the contents from the action of light, as well as being tightly closed to avoid external contamination.

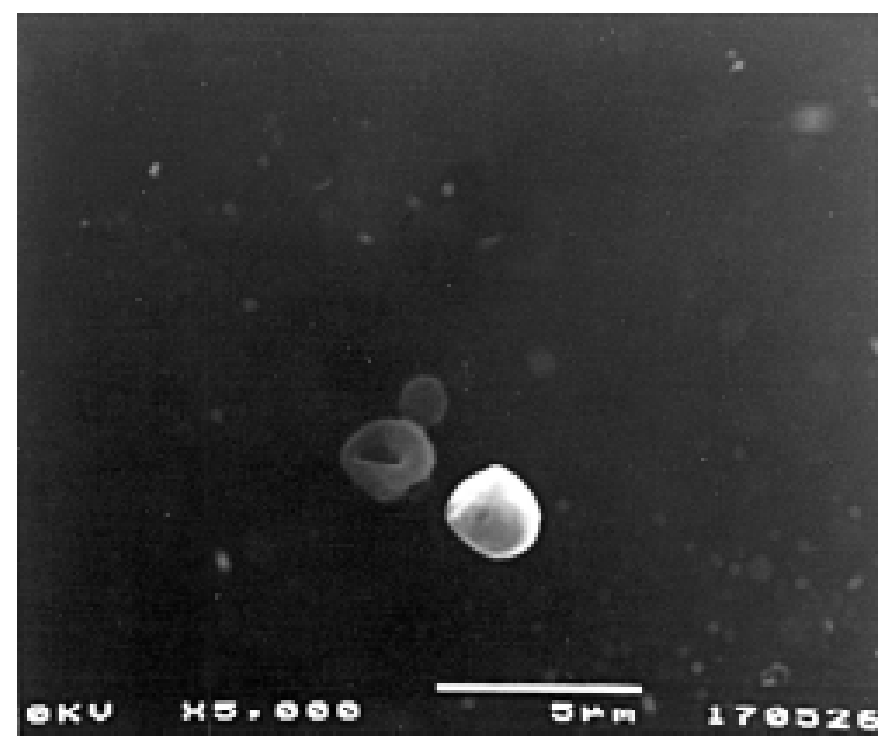

Figure 6. Scanning electron micrograph showing adhesion of Candida albicans cells on aluminum unlined surface (x5.000) JEOL-JSM T330A.

Our results showed that aluminum both unlined and lined with epoxy resin used for packaging pharmaceutical products permit microbial adherence.

\section{ACKNOWLEDGEMENTS}

This work was supported in part by Núcleo de Atendimento à Comunidade-NAC - Unidade Auxiliar Integrada à Faculdade de Ciências Farmacêuticas, câmpus de Araraquara-UNESP (Brazil) and in part by the Instituto de Química, câmpus de Araraquara-UNESP (Brazil).

\section{RESUMO}

\section{Avaliação química e microbiológica da superfície interna dos tubos de alumínio não revestido e revestido com resina epóxi por meio de microscópio estereoscópio e eletrônico de varredura}

A superfície interna das bisnagas fabricadas com alumínio não revestido e revestido com resina epóxi, utilizadas para acondicionar cremes, pomadas, géis, etc., foram avaliadas quimicamente e por métodos microbiológicos correlacionados com a aderência de microrganismos. A prova da porosidade e da resistência à remoção da resina foi observada por meio do microscópio eletrônico de varredura (Topcon FM300) e estereoscópio Leica (MZ12) acoplado a Sistema de Digitalização de Imagens. Para avaliar a ação dos microrganismos foram utilizados corpos-de-prova esterilizados (discos de $10 \mathrm{~mm}$ de 
diâmetro), imersos em caldo Mueller Hinton (Difco) e colocados em tubos de polipropileno com tampa de rosca (Corning). Foram inoculados tubos com meio de cultura para cada uma das suspensões bacterianas $\left(10^{9} \mathrm{UFC} / \mathrm{mL}\right)$ de Streptococcus agalactiae, Staphylococcus aureus, Acinetobacter lwoffii e Candida albicans, incubados a $37^{\circ} \mathrm{C}$, sob agitação constante durante 12 dias. O meio de cultura era trocado a cada 3 dias. Após esse período, os corpos-de prova foram removidos, processados e observados em microscópio eletrônico de varredura JEOL-JSM (T330A). A observação por meio do microscopio eletrônico de varredura mostrou a aderência e a formação de biofilme sobre a superfície de alumínio não revestido e revestido com resina epóxi.

Palavras-chave: Aderência microbiana, biofilme, biofouling, embalagens de alumínio.

\section{REFERENCES}

1. Agência Nacional de Vigilância Sanitária RDC n 33/2000. In: Anfarmag, p.22, 2000.

2. Alcoa: http://www.alcoa.com.br

3. Bryers, J.D. Biofilm Formation and Persistence. In: Bryers, J.D. (eds). Biofilms II: Process Analysis and Applications. Wiley-Liss Inc., New York, 2000, 432p.

4. CBE-Bandeirante de Embalagens Ltda. Metodologia de Análise para Bisnagas de Alumínio. 1994, 17p.

5. Characklis, W.G.; Marshall, K.C. Biofilms. Wiley-Interscience, New York, 1990, 796p.
6. Charlot, G. L'Analyse Qualitative et Les Réactions en Solution. Manon \& Cie, Paris, 1957, p.175.

7. Clark, G.L.; Hawley, G. Encyclopedia de Química. Omega, Barcelona, 1961, 1479p

8. Corning Incorporated - Corning, New York, 14831, [on line] www.scienceproducts.corning.com

9. Denyer, S.P.; Gorman, S.P.; Sussman, M. Microbial Biofilms: Formation and Control. Blackwell Scientific Publications, Oxford, 1993, 336p.

10. Difco Manual of Dehydrated Culture Media and Reagents for Microbiology. Difco Laboratories, Detroit, 1984, 1155p.

11. Ferreira, A.O. Guia Prático de Farmácia Magistral. Anderson de Oliveira Ferreira (ed), Juiz de Fora, 2000, 390p.

12. Lucas, V. Incompatibilidades Medicamentosas. Editora Científica, Rio de Janeiro, 1957, p.272-273.

13. Martindale, W. Extra Pharmacopocia-30. The Pharmaceutical Press, Londres, 1997, 1334p.

14. Montanaro, L.; Arciola, C. Studying Bacterial Adhesion To Irregular or Porous Surfaces. In: An, Y.H.; Friedman, R.J. (eds) Handbook of Bacterial Adhesion: Principles, Methods, and Applications. Humana Press Inc., New Jersey, 2000, p.331-370.

15. Pizzolitto, E.L.; Ito, I.Y.; Guastaldi, A.C. Corrosion Induced by Streptococcus mutans (in vitro) Observed on Restorative Dental Materials. In: Sequeira, C.A.C. Microbial Corrosion. v.29. IOM Communications Ltd, London, 2000, p.179-189.

16. Pozetti, G.L. Controle de Qualidade em Homeopatia, IHFL, Ribeirão Preto, 1988, p.289-301.

17. Pozetti, G.L. Em Defesa da Farmacopéia Homeopática Brasileira. Brasilia, 1998, 76p.

18. Walker, J.T.; Bradshaw, D.J.; Bennet, A.M.; Fulford, M.R.; Martin, M.P.D. Microbial biofilm formation and contamination of dentalunit water systems in general dental practice. Appl. Environ. Microbial., 66: 3363-3367, 2000.

19. Zobell, C. The effect of solid surfaces upon bacterial activity. $J$. Bacteriol., 46: 39-56, 1943. 